\title{
Neoadjuvant chemotherapy is a risk factor for bronchopleural fistula after pneumonectomy for non-small cell lung cancer
}

\author{
Ozgur Samancilar, Seyda Ors Kaya, Ozan Usluer, Taner Ozturk \\ Department of Thoracic Surgery, Dr. Suat Seren Chest Diseases and Thoracic Surgery Research \\ and Training Hospital, Izmir, Turkey
}

Kardiochirurgia i Torakochirurgia Polska 2014; 11 (1): 40-43

\begin{abstract}
Introduction: Performing pneumonectomy after neoadjuvant chemotherapy is still controversial. Bronchopleural fistula is a major complication after pneumonectomy. In this study the effect of neoadjuvant chemotherapy on postpneumonectomy bronchopleural fistula was investigated.

Material and methods: A retrospective review of patients who underwent pneumonectomy for non-small cell lung cancer from January 2005 to December 2011 was undertaken. The major complications and operative mortality were analyzed and compared between the patients having neoadjuvant chemotherapy and patients having surgery only.

Results: One hundred and seventy-seven pneumonectomies (77 right and 100 left) were performed during the study period and 49 of these patients (27.7\%) received neoadjuvant chemotherapy. Median age was 60 years (range, 32 to 80). The bronchopleural fistula rate was $26.5 \%$ (13/49) in the neoadjuvant group versus $3.1 \%(4 / 128)$ in the surgery alone group $(p=0.029)$. The bronchopleural fistula rate was $16.9 \%(13 / 77)$ in the right pneumonectomy group vs. $4 \%(4 / 100)$ in the left pneumonectomy group $(p=0.004)$. Overall operative mortality was $5.6 \%$. Mortality in the neoadjuvant group was $8.2 \%$ vs. $4.7 \%$ in the surgery only group $(p=0.37)$.

Conclusions: Neoadjuvant chemotherapy and right pneumonectomy is a major risk factor for bronchopleural fistula. Especially right pneumonectomy should be avoided after induction therapy. Key words: pneumonectomy, neoadjuvant chemotherapy, bronchopleural fistula.
\end{abstract}

\section{Streszczenie}

Wstęp: Wykonywanie pneumonektomii po chemioterapii neoadiuwantowej wciąż budzi kontrowersje. Przetoka oskrzelowo-opłucnowa jest istotnym powikłaniem po pneumonektomii. W pracy przeanalizowano oddziaływanie chemioterapii neoadiuwantowej na powstawanie przetok oskrzelowo-opłucnowych.

Materiat i metody: Niniejszy retrospektywny przegląd dotyczy chorych, których poddano pneumonektomii w ramach leczenia niedrobnokomórkowego raka płuca pomiędzy styczniem 2005 a grudniem 2011 r. Przeanalizowano istotne powikłania oraz śmiertelność operacyjną, a następnie porównano je pomiędzy pacjentami leczonymi za pomocą chemioterapii neoadiuwantowej oraz pacjentami leczonymi wyłącznie chirurgicznie.

Wyniki: W okresie objętym badaniem wykonano 177 pneumonektomii (77 prawych i 100 lewych), a 49 spośród pacjentów $(27,7 \%)$ zostało poddanych chemioterapii neoadiuwantowej. Mediana wieku wyniosła 60 lat (zakres: 32-80 lat). Wskaźnik przetok oskrzelowo-opłucnowych wyniósł 26,5\% (13/49) w grupie poddanej terapii neoadiuwantowej w porównaniu z 3,1\% (4/128) w grupie leczonej wyłącznie chirurgicznie $(p=0,029)$. Wskaźnik przetok oskrzelowo-opłucnowych wyniósł 16,9\% (13/77) w grupie poddanej prawej pneumonektomii w porównaniu z 4\% $(4 / 100)$ w grupie poddanej lewej pneumonektomii $(p=0,004)$. Całkowita śmiertelność operacyjna wyniosła 5,6\%. Śmiertelność w grupie neoadiuwantowej wyniosła 8,2\% w porównaniu z 4,7\% w grupie leczonej wyłącznie chirurgicznie $(p=0,37)$.

Wnioski: Chemioterapia neoadiuwantowa oraz prawa pneumonektomia stanowią istotne czynniki ryzyka rozwoju przetok oskrzelowo-opłucnowych. Po terapii indukcyjnej należy w szczególności unikać przeprowadzania prawych pneumonektomii.

Stowa kluczowe: pneumonektomia, chemioterapia neoadiuwantowa, przetoka oskrzelowo-opłucnowa.

Address for correspondence: Ozan Usluer, Dr. Suat Seren Chest Disease and Thoracic Surgery Training and Research Hospital, Department of Gogus Hastanesi Tepecik Yenisehir KonakYenisehir, Izmir, Turkey, fax: +90 232458 72 62, e-mail: ozanusluer@yahoo.com 


\section{Introduction}

Pneumonectomy is associated with increased morbidity and mortality rates when compared to other pulmonary resections [1]. There are several controversial results in the literature about the effect of induction therapy on morbidity and mortality of pneumonectomy applied for the resection of non-small cell lung cancer, which questions the feasibility and benefit of performing such a high-risk procedure [2-10].

Bronchopleural fistula (BPF) after pneumonectomy is a major problem in thoracic surgical practice. Some risk factors are defined which might be the cause or a predictor of this complication [11-15]. In this study, the effect of neoadjuvant chemotherapy on postpneumonectomy bronchopleural fistula was investigated.

\section{Material and methods}

A retrospective review of patients who underwent pneumonectomy for non-small cell lung cancer from January 2005 to December 2011 was undertaken. The patients received neoadjuvant chemoradiation and patients having incomplete resection were excluded from the study. The data were obtained from the electronic and paper medical records, patients' charts and follow-up records. The retrospective study was approved by the Institutional Review Board. Informed consent was obtained from all the patients before the operation.

Computed tomography (CT) scan, positron emission tomography (PET) scan, and fiberoptic bronchoscopy were applied to all patients. Invasive mediastinal staging procedures such as endobronchial ultrasound (EBUS) biopsy of mediastinal lymph nodes, mediastinoscopy, and videoassisted thoracoscopic surgery (VATS) were used when there was a suspicion of a metastatic lymph node on PET scan. The physiologic evaluation of the patients considered for resection was performed according to the published guidelines [16].

Three cycles of platinum based chemotherapy were applied to patients having histologically proven ipsilateral mediastinal lymph node (N2) metastases or locally advanced tumor when there was a doubt of resectability.

Single-lung ventilation was obtained through a doublelumen endotracheal tube and epidural analgesia was performed routinely for pain management. A serratus anterior muscle sparing posterolateral thoracotomy was performed and mediastinal lymph node dissection was added to pneumonectomy in all cases. Bronchial staplers were used to divide the bronchus in most of the patients. The bronchial stump was not reinforced routinely according to the surgeon's preference, and mediastinal pleura was used most frequently when reinforcement was applied. The patients were taken to a postoperative intensive care unit after being extubated in the operating room if possible and then transferred to a thoracic ward whenever cardiopulmonary functions were stable.

Major cardiopulmonary complications such as arrhythmia requiring medical treatment, respiratory failure defined as reintubation, placement of tracheostomy and need for ventilation more than 48 hours after surgery and bronchopleural fistula, as well as operative mortality defined as death from any cause within 30 days of surgery were recorded and compared between the patients having neoadjuvant chemotherapy and patients having surgery only.

Statistical Package for the Social Sciences (SPSS) version 19 was used for analyzing the data. The associations among the categorical variables and numerically coded qualitative variables between the two groups were examined by using Fisher's exact test. The descriptive statistics of the quantitative variables were reported as means, standard deviations, medians, minimums and maximums while the qualitative variables were summarized as counts $(n)$ and percentages (\%). The obtained statistics were reported with their $95 \%$ confidence intervals and the analysis results with $p<0.05$ were considered as statistically significant.

\section{Results}

There were 168 (94\%) male and 9 (6\%) female patients in the study group with a median age of 60 years (range, 32 to 80). Of the 177 pneumonectomies (77 right and 100 left) performed during the study period, 49 of these patients $(27.7 \%)$ received neoadjuvant chemotherapy. Neoadjuvant chemotherapy was applied to 12 patients for having histologically proven ipsilateral mediastinal lymph node (N2) metastases and to 37 patients for having a locally advanced tumor and there was a doubt of resectability. The characteristics of patients who received neoadjuvant chemotherapy are shown in Table I.

The major cardiopulmonary complication rate was higher in the neoadjuvant group (44.8\% vs. $4.6 \%)(p=0.002)$ (Table II). The overall bronchopleural fistula rate was $9.6 \%$ (17/177). The bronchopleural fistula rate was 26.5\% (13/49) in the neoadjuvant group versus 3.1\% (4/128) in the surgery alone group and the difference between the two groups was statistically significant $(p=0.029)$. Additionally the bronchopleural fistula rate was $16.9 \%(13 / 77)$ in the right

Tab. I. Characteristics of the patients $(n=49)$ who received neoadjuvant chemotherapy

\begin{tabular}{lc}
\multicolumn{2}{l}{ Variables } \\
\hline Sex & 56 \\
\hline Male $(n)$ & $48(98 \%)$ \\
\hline Female $(n)$ & $1(2 \%)$ \\
\hline Laterality & $22(44.8 \%)$ \\
\hline Right $(n)$ & $27(55.2 \%)$ \\
\hline Left $(n)$ & $37(75.5 \%)$ \\
\hline N2 disease $(n)$ & $12(24.5 \%)$ \\
\hline $30-$ day mortality & $8.2 \%$ \\
\hline
\end{tabular}


Tab. II. Comparison of major cardiopulmonary complications between the two groups

\begin{tabular}{lccc} 
& $\begin{array}{c}\text { Neoadjuvant } \\
\text { group }(n)\end{array}$ & $\begin{array}{c}\text { Surgery only } \\
\text { group }(n)\end{array}$ & $p$ \\
\hline Bronchopleural fistula & $13(26.5 \%)$ & $4(3.1 \%)$ & 0.029 \\
\hline Arrhythmia & $6(12.2 \%)$ & $1(0.7 \%)$ & 0.059 \\
\hline Respiratory failure & $3(6.1 \%)$ & $1(0.7 \%)$ & 0.317 \\
\hline Total & $22(44.8 \%)$ & $6(4.6 \%)$ & 0.002 \\
\hline
\end{tabular}

pneumonectomy group versus $4 \%(4 / 100)$ in the left pneumonectomy group $(p=0.004)$.

Overall 30-day operative mortality was 5.6\% (10/177). Mortality rates were higher in the neoadjuvant group $(8.2 \%$ versus $4.7 \%$ in the surgery only group) but the results were not statistically significant $(p=0.37)$. The mortality rate was $6.5 \%(5 / 77)$ in the right pneumonectomy group versus $5 \%(5 / 100)$ in the left pneumonectomy group $(p=670)$.

\section{Discussion}

Pneumonectomy after neoadjuvant therapy appears to be a high-risk procedure. Despite the recommendation by the American College of Chest Physicians to avoid pneumonectomy after induction therapy [17], there are several retrospective studies and clinical trials published investigating the morbidity and mortality after this treatment and most of them focused on the mortality rates [18-20]. Martin [21] reported a mortality of $23.9 \%$ after right pneumonectomy following induction treatment. D'Amato [3] revealed a mortality rate of $21 \%$ and concluded that induction chemotherapy increases the risk of operative mortality after pneumonectomy. $\mathrm{Kim}$ [22] also reported a 20\% 90-day mortality after right-sided pneumonectomy. On the other hand, there are also some recent studies published showing that this high-risk procedure can be performed with acceptable mortality rates from 3 to $10 \%$ [2, 3, 5-8, 10, 23]. More recently Kim et al. [4] reported a meta-analysis of perioperative mortality after neoadjuvant therapy and pneumonectomy. They found overall 30-day and 90-day mortality rates of $7 \%$ and $12 \%$ respectively. 30 - and 90 -day cumulative mortality rates for right pneumonectomy were $11 \%$ and $20 \%$. The overall 30-day operative mortality was 5.6\% (10/177) in our series. Mortality rates were higher in the neoadjuvant group ( $8.2 \%$ versus $4.7 \%$ in the surgery only group), which was in accordance with the recently published data, but the difference was not statistically significant $(p=0.37)$.

Bronchopleural fistula is a severe complication of pneumonectomy which increases the postoperative mortality. There are several risk factors defined that may cause postpneumonectomy bronchopleural fistula. Low preoperative serum albumin level, hyperglycemia, previous steroid therapy, poor predicted postpneumonectomy forced expiratory volume in 1 second, long bronchial stump, mechanical ventilation, right pneumonectomy, adjuvant radiotherapy and pneumonia after the operation are shown to be some of the risk factors [11-15]. Although some bronchopleural fistula rates have been revealed in several studies focusing on the mortality of pneumonectomy after induction therapy, the effect of neoadjuvant treatment on formation of postpneumonectomy bronchopleural fistula has not been evaluated thoroughly. Refai [2] reported that there was no increase in the postpneumonectomy bronchopleural fistula rate after induction treatment. D'Amato [3] reported a bronchopleural fistula rate of $8.8 \%$ in the induction therapy group versus $7.3 \%$ in the surgery alone group without any significant difference between the two groups. There are several studies in the literature that have shown an association between induction treatment and increased risk of bronchopleural fistula after pneumonectomy. Ucvet [13] and Panagopoulos [15] also found that neoadjuvant therapy is a significant risk factor for bronchopleural fistula. In our previous ex vivo study, we found that the tensile strength of pulmonary structures such as the pulmonary artery, pulmonary vein, and bronchus decreases and fibrosis grade increases after neoadjuvant chemotherapy, which may be a cause of the bronchopleural fistula [26]. In our present study, the incidence of postpneumonectomy bronchopleural fistula was significantly higher in the induction therapy group.

\section{Conclusions}

Neoadjuvant chemotherapy and right pneumonectomy are risk factors for postpneumonectomy bronchopleural fistula. Especially right pneumonectomy should be avoided after induction therapy if possible.

\section{References}

1. Allen MS, Darling GE, Pechet TT, Mitchell JD, Herndom JE 2nd, Landreneau RJ, Inculet RI, Jones DR, Meyers BF, Harpole DH, Putnam JB Jr, Rusch VW; ACOSOG Z0030 Study Group. Morbidity and mortality of major pulmonary resections in patients with early-stage lung cancer: initial results of the randomized, prospective ACOSOGZ0030 trial. Ann Thorac Surg 2006; 81: 1013-1020.

2. Refai M, Brunelli A, Rocco G, Ferguson MK, Fortiparri SN, Salati M, La Rocca A, Kawamukai K. Does induction treatment increase the risk of morbidity and mortality after pneumonectomy? A multicentre case-matched analysis. Eur J Cardiothorac Surg 2010; 37: 535-539.

3. d'Amato TA, Ashrafi AS, Schuchert MJ, Alshehab DS, Seely AJ, Shamji FM, Maziak DE, Sundaresan SR, Ferson PF, Luketich JD, Landreneau RJ. Risk of pneumonectomy after induction therapy for locally advanced non-small cell lung cancer. Ann Thorac Surg 2009; 88: 1079-1085.

4. Kim AW, Boffa DJ, Wang Z, Detterbeck FC. An analysis, systematic review, and meta-analysis of the perioperative mortality after neoadjuvant therapy and pneumonectomy for non-small cell lung cancer. J Thorac Cardiovasc Surg 2012; 143: 55-63.

5. Steger V, Spengler W, Hetzel J, Veit S, Walker T, Mustafi M, Friedel G, Walles T. Pneumonectomy: calculable or non-tolerable risk factor in trimodal therapy for Stage III non-small-cell lung cancer? Eur J Cardiothorac Surg 2012; 41: 880-885.

6. Barnett SA, Rusch VW, Zheng J, Park BJ, Rizk NP, Plourde G, Bains MS, Downey RJ, Shen R, Kris MG. Contemporary results of surgical resection of non-small cell lung cancer after induction therapy: a review of 549 consecutive cases. J Thorac Oncol 2011; 6: 1530-1536.

7. Weder W, Collaud S, Eberhardt WE, Hillinger S, Welter S, Stahel R, Stamatis G. Pneumonectomy is a valuable treatment option after neoadjuvant therapy for stage III non-small-cell lung cancer. J Thorac Cardiovasc Surg 2010; 139: 1424-1430. 
8. Thibout Y, Guibert B, Bossard N, Tronc F, Tiffet O, de la Roche E, Mulsant P, Gamondes JP, Baulieux J, Remontet L, Geriniere L, Souquet PJ. Is pneumonectomy after induction chemotherapy for non-small cell lung cancer a reasonable procedure? A multicenter retrospective study of 228 cases. I Thorac Oncol 2009; 4: 1496-1503.

9. Kappers I, van Sandick JW, Burgers SA, Belderbos JS, van Zandwijk N, Klomp HM. Surgery after induction chemotherapy in stage IIIA-N2 nonsmall cell lung cancer:why pneumonectomy should be avoided. Lung Cancer 2010; 68: 222-227.

10. Gudbjartsson T, Gyllstedt E, Pikwer A, Jönsson P. Early surgical results afterpneumonectomy for non-small cell lung cancer are not affected by preoperative radiotherapy and chemotherapy. Ann Thorac Surg 2008; 86: 376-382.

11. Matsuoka K, Misaki N, Sumitomo S. Preoperative hypoalbuminemia is a risk factor for late bronchopleural fistula after pneumonectomy. Ann Thorac Cardiovasc Surg 2010; 16: 401-405.

12. Algar FJ, Alvarez A, Aranda JL, Salvatierra A, Baamonde C, López-Pujol FJ. Prediction of early bronchopleural fistula after pneumonectomy: a multivariate analysis. Ann Thorac Surg 2001; 72: 1662-1667.

13. Uçvet A, Gursoy S, Sirzai S, Erbaycu AE, Ozturk AA, Ceylan KC, Kaya SO. Bronchial closure methods and risks for bronchopleural fistula in pulmonary resections: how a surgeon may choose the optimum method? Interact Cardiovasc Thorac Surg 2011; 12: 558-562.

14. Jichen QV, Chen G, Jiang G, Ding J, Gao W, Chen C. Risk factor comparison and clinical analysis of early and late bronchopleural fistula after non-small cell lung cancer surgery. Ann Thorac Surg 2009; 88: 1589-1593.

15. Panagopoulos ND, Apostolakis E, Koletsis E, Prokakis C, Hountis P, Sakellaropoulos G, Bellenis I, Dougenis D. Low incidence of bronchopleural fistula after pneumonectomy for lung cancer. Interact Cardiovasc Thorac Surg 2009; 9: 571-575.
16. Colice GL, Shafazand S, Griffin JP, Keenan R, Bolliger CT; American College of Chest Physicians. Physiologic evaluation of the patient with lung cancer being considered for resectional surgery: ACCP evidenced-based clinical practice guidelines ( ${ }^{\text {nd }}$ edition). Chest 2007; 132: 161S-177S

17. Alberts WM; American College of Chest Physicians. Diagnosis and management of lung cancer executive summary: ACCP evidence-based clinical practice guidelines ( $2^{\text {nd }}$ edition). Chest 2007; 132: 1S-19S

18. Martin J, Ginsberg RJ, Abolhoda A, Bains MS, Downey RJ, Korst RJ, Weigel TL, Kris MG, Venkatraman ES, Rusch VW. Morbidity and mortality after neoadjuvant therapy for lung cancer: the risks of right pneumonectomy. Ann Thorac Surg 2001; 72: 1149-1154.

19. Kim AW, Faber LP, Warren WH, Basu S, Wightman SC, Weber JA, Bonomi P, Liptay MJ. Pneumonectomy after chemoradiation therapy for non-small cell lung cancer:does "side" really matter? Ann Thorac Surg 2009; 88: 937-943.

20. Gaissert HA, Keum DY, Wright CD, Ancukiewicz M, Monroe E, Donahue DM, Wain JC, Lanuti M, Allan JS, Choi NC, Mathisen DJ. POINT: Operative risk of pneumonectomy-influence of preoperative induction therapy. J Thorac Cardiovasc Surg 2009; 138: 289-294.

21. Fowler WC, Langer CJ, Curran WJ Jr, Keller SM. Postoperative complications after combined neoadjuvant treatment of lung cancer. Ann Thorac Surg 1993; 55: 986-989.

22. Van Schil P, Van Meerbeeck J, Kramer G, Splinter T, Legrand C, Giaccone G, Manegold C, van Zandwijk N. Morbidity and mortality in the surgery arm of EORTC 08941 trial. Eur Respir J 2005; 26: 192-197.

23. Ceylan KC, Kaya SO, Samancilar O, Gursoy S, Ucvet A. The effects of neoadjuvant chemotherapy on pulmonary structures: a quantitative analysis. Thorac Cardiovasc Surg 2012; 60: 111-115. 